\title{
Weight gain and control of endo- and ectoparasites of beef heifers treated with allopathic, herbal and homeopathic drugs
}

Ganho de peso e controle de endo e ectoparasitas de novilhas de corte tratadas com medicamentos alopáticos, fitoterápicos e homeopáticos

João Batista Catto ${ }^{1 *}$; Ivo Bianchin ${ }^{1}$; Gelson Luis Dias Feijó ${ }^{1}$; Flábio Ribeiro Araújo'; Carlos Alberto do Nascimento Ramos²; Ana Beatriz Canevari Casteláo

${ }^{1}$ Centro Nacional de Pesquisa de Gado de Corte, Empresa Brasileira de Pesquisa Agropecuária - EMBRAPA, Campo Grande, MS, Brasil

${ }^{2}$ Laboratório de Imunologia, Centro Nacional de Pesquisa de Gado de Corte, Empresa Brasileira de Pesquisa Agropecuária - EMBRAPA, Campo Grande, MS, Brasil

Received April 24, 2013

Accepted August 2, 2013

\begin{abstract}
The aim of this study was to evaluate the efficacy of herbal, homeopathic and allopathic treatments for parasites in beef heifers during two experimental cycles of 318 and 313 days. Treatments: NC - negative control (untreated); $\mathrm{HH}$ - treated with homeopathic preparation Homeo bovis Parasitário ${ }^{\circledR}$; PC - (positive control) - treated with 10\% moxidectina ${ }^{\circledR}$ and an acaricide formulation of cypermethrin, chlorpyrifos and piperonyl butoxide ${ }^{\circledR}$; HF - treated with homeopathic preparation Fator $\mathrm{C} \& \mathrm{MC}^{\circledR}$; and FN - treated with neem cake (torta de neem ${ }^{\circledR}$ ) and with neem oil (óleo de neem ${ }^{\circledR}$ ). Parasite egg count (EPG), horn fly (Haematobia irritans) and tick (Rhipicephalus (Boophilus) microplus) assessment and animal weighting were performed at 28-day intervals. Blood samples were collected at the first cycle to assess the immune response. Horn fly infestation was not affected by any treatment $(\mathrm{P}>0.05)$. The mean number of ticks, which was low in both cycles, was lower $(\mathrm{P}<0.05)$ in the first cycle in animals that received $\mathrm{PC}$ treatment. In both experimental cycles, the mean EPG of the PC-treated animals was lower $(\mathrm{P}<0.05)$ than the animals receiving other treatments. Treatments had no effect on the immune response $(\mathrm{P}>0.05)$. The animals treated with allopathic drugs were 22 to $30 \mathrm{~kg}$ heavier $(\mathrm{P}<0.05)$ than untreated animals or animals treated with alternative drugs.
\end{abstract}

Keywords: Beef cattle, tick, nematodes, horn fly, anthelmintics, alternative control.

\section{Resumo}

O objetivo do trabalho foi avaliar a eficácia de tratamentos fitoterápicos, homeopáticos e alopáticos contra ecto e endoparasitas na recria de novilhas, em dois ciclos experimentais subsequentes de 318 e 313 dias. Tratamentos: $\mathrm{CN}$ - controle negativo - não tratado; tratamento HH - tratado com homeopático Homeo bovis Parasitário ${ }^{\circledR}$; tratamento $\mathrm{CP}$ - controle positivo - tratado com moxidectina $10 \%{ }^{\circledR}$ e uma formulação acaricida contendo cypermetrina, clorpirifós e butóxido de piperonila ${ }^{\circledR}$; tratamento HF - tratado com homeopático Fator $C \& M C^{\circledR}$ e tratamento FN - tratados com torta de neem ${ }^{\circledR}$ e com óleo de neem ${ }^{\circledR}$. A contagem de ovos nas fezes (OPG), a infestaçáo por Haematobia irritans, Rhipicephalus (Boophilus) microplus e pesagem dos animais foram realizadas em intervalos de 28 dias. No primeiro ciclo foi coletado sangue para avaliar a resposta imume. A infestaçáo por mosca-dos-chifres não foi influenciada por nenhum dos tratamentos $(\mathrm{P}>0,05)$. Nos dois ciclos o número médio de carrapatos foi baixo e apenas no primeiro foi menor $(\mathrm{P}>0.05)$ no tratamento $\mathrm{CP}$ em relação aos demais. A média de OPG no tratamento $\mathrm{CP}$ foi mais baixa que nos demais tratamentos nos dois ciclos experimentais $(\mathrm{P}<0,05)$. Náo houve efeito de tratamentos na resposta imune. Os animais do tratamento $\mathrm{CP}$ ganharam entre 22 a $30 \mathrm{~kg}$ de peso vivo a mais $(\mathrm{P}<0,05)$ que os náo tratados ou tratados com medicamentos alternativos.

Palavras-chave: Gado de corte, carrapato, nematódeos, mosca-dos-chifres, anti-helmínticos, controle alternativo.

\footnotetext{
${ }^{*}$ Corresponding author: Joáo Batista Catto

Embrapa Gado de Corte, Av. Rádio Maia, 830, CEP 79106-550,

Campo Grande, MS, Brasil

e-mail: joao.catto@embrapa.br
} 


\section{Introduction}

Currently, most food production is based on the intensive use of chemically synthesized inputs, mechanization and selective breeding. The current food production model is being questioned in relation to the environment, animal welfare and public health. The demand for production of food without contaminants and for the use of processes that are less dependent on synthetic inputs and less harmful to the environment is growing.

The increase in Brazilian beef cattle production achieved in recent years has enabled Brazil to become the world leader in beef exports. Because Brazil possesses tropical and subtropical regions in which parasitic diseases are common, the use of anti-parasitic drugs (APs) in its beef production industry is significant; APs accounted for $24 \%$ of a total of $\mathrm{R} \$ 3.4$ billion spent on veterinary products marketed in 2011 (SINDAN, 2008).

The presence of APs residues in meat currently represents a non-tariff barrier to foreign trade and tends to increase consumers' questions and concerns regarding the presence of drugs in food. The frequent use (and misuse) of APs has also resulted in the emergence of resistant populations of endo- and ectoparasites (CHAGAS et al., 2008; GRAF et al., 2004; KAMINSKY et al., 2008; BARROS et al., 2012). For these reasons, as well as due to their lower cost, the absence of residues in meat and milk, their low environmental impact, their ease of use as food additives, the use of homeopathic and herbal medicines as APs is significantly increasing in Brazil. Currently, several million head of cattle in the country are being treated with homeopathic and herbal formulations in organic and conventional systems. However, despite their increasing use, the efficacy of these control measures has not been validated based on scientific evidence obtained under field conditions (CHAGAS et al., 2008; MOLENTO, 2009; COSTA-JUNIOR; FURLONG, 2011).

Significant differences in the number of engorged female ticks of R. (B.) microplus (SILVA et al., 2008) and in the weight of engorged female ticks and oviposition, hatching rate and reproductive efficiency (GAZIM et al., 2010) were found in heifers and dairy cows that were naturally infested, untreated or treated with biotherapics. In contrast, Signoretti et al. (2008) found no significant difference in infestation, and Costa-Junior and Furlong (2011) found no difference in the number or weight of engorged female ticks or the rate of egg production in untreated experimentally infested animals and animals treated with homeopathic biotherapics.

Several recently published studies have presented promising in vitro results on the effect of Azadirachta indica (neem) seed oil and extracts on $R$. (B.) microplus larvae and engorged females (BORGES et al., 2011), but few trials of these agents have been conducted in naturally or experimentally infested animals. Although several products from the neem plant, primarily oil, seed cake and ground dry leaf, are marketed as agents for the control of ectoand endoparasites in ruminants, there are no license of the use of herbal drugs against bovine endo- and ectoparasites in Brazil. The use of homeopathic and herbal drugs is recommended in organic production systems (BRASIL, 2008).
The aim of this study was to evaluate the efficacy of homeopathic and herbal medicines in controlling endo- and ectoparasites of beef cattle in a long-term study using the following parameters: parasitological stool examination, infestation by ectoparasites, humoral immune response and weight gain.

\section{Materials and Methods}

\section{Study site, animals and experimental design}

The experiment was conducted in Campo Grande at the National Beef Cattle Research Center of the Brazilian Agricultural Research Corporation (Centro Nacional de Pesquisa de Gado de Corte da Empresa Brasileira de Pesquisa Agropecuária, EMBRAPA) in the Midwest (Centro-Oeste) region of Brazil. The climate of this region is characterized by the occurrence of a wet period in summer and by dry winters. The mean annual rainfall is $1550 \mathrm{~mm}$, with a welldefined dry season. The monthly average temperatures are above $17^{\circ} \mathrm{C}$, and the average maximum temperature is below $35^{\circ} \mathrm{C}$.

A 60-ha experimental area of Brachiaria brizantha, which was maintained under grazing before the start of the experiment, was divided into 15 paddocks of four hectares each. The soil was fertilized with $200 \mathrm{~kg} /$ ha granular fertilizer NPK 20-10-20. Two experimental cycles were conducted, one from May of 2010 through April of 2011 and one from June of 2011 to April of 2012. In each cycle 180 newly weaned 7-9 months old Brangus (5:8 Aberdeen Angus:Brahman) heifers from the same herd, stratified by weight, the number of nematode eggs (EPG) and the number of engorged ticks were distributed at random in 15 groups of 12 animals each. The 15 groups of animals were randomly distributed into 15 paddocks and to one of five treatments. In the second cycle, the distribution of the treatments among the paddocks remained the same.

The treatments used were as follows: NC - negative control (untreated); HH - daily treatment with Homeo bovis Parasitário ${ }^{\circledR}$ homeopathic preparation (Real H, Campo Grande, Brazil); PC (positive control) - treated with $10 \%$ moxidectin ${ }^{\circledR}$ (Fort Dodge, Campinas, Brazil) in June and September and three consecutive times with acaricide formulation ${ }^{\circledR}$ pour-on (Vetebrands, Porto Alegre, Brazil) at intervals of 28 days from September; HF - daily treatment with Fator $\mathrm{C} \& \mathrm{MC}^{\circledR}$ (Flora e Fauna Arenales, Presidente Prudente, São Paulo, Brazil), and FN - daily treatment with neem $^{\circledR}$ cake and neem ${ }^{\circledR}$ oil (Bioneem, Aracuai, Brazil) as in the PC treatment. The PC treatment was used as a positive control because previous trials have shown significant weight gain in strategically treated animals compared to untreated controls (BIANCHIN et al., 1995, 2007; CATTO et al., 2009). In the first cycle the PC animals was treated in June with $1 \%$ doramectina ${ }^{\circledR}$ (Pfizer, São Paulo, Brazil).

The Fator $\mathrm{C} \& \mathrm{MC}{ }^{\circledast}$ contains nosodes dynamized: Rhipicephalus (Boophilus) microplus, Amblyomma cajennense, Haematobia irritans, Musca domestica, Bunostomum sp., Haemonchus contortus, H. placei, Nematodirus sp., Oesophagostomum sp., Ostertagia ostertagi, Strongyloides sp., Trichostrongylus axei, Trichostrongylus colubriformis, Trichuris sp., Eimeria sp., Cysticercus cellulosae, Dermatobia hominis, energized at $\mathrm{CH} 12$, Bixa orellana $0,75 \mathrm{~g}$, Sacarose q.s.p. 
$100 \mathrm{~g}$. Homeo bovis parasitário ${ }^{\circledR}$ contains nosodes: Rhipicephalus (Boophilus) microplus, Haematobia irritans, Haemonchus contortus, Cochliomya hominivorax energized at $10^{-400}$, Artemisia maritima e sulphur iodatum energized at $10^{-60}$.

The animals were supplemented with $200 \mathrm{~g} / \mathrm{animal} / \mathrm{day}$ of protein meal, and all treatments products were used according to the manufacturers' recommendations: Fator C\&MC ${ }^{\circledR}$ 1,6 g/animal/day; Homeo Bovis Parasitário ${ }^{\circledR} 4 \mathrm{~g} / \mathrm{animal} /$ day, Neem cake ${ }^{\circledR} 4 \mathrm{~g} / \mathrm{animal} /$ day, Neem oil ${ }^{\circledR} 10 \mathrm{~mL} / 100 \mathrm{~kg}$, acaricide formulation $1 \mathrm{~mL} / 10 \mathrm{~kg}$, Doramectin $1 \% 1 \mathrm{~mL} / 50 \mathrm{~kg}$ and Moxidectin $10 \% 1 \mathrm{~mL} / 100 \mathrm{~kg}$. Homeopathic products and neem cake were added to the diet, and the dose of homeopathic products and neem cake was doubled in the second experimental cycle. Mineral mixture was provided ad libitum in separate troughs. The paddocks were sampled at the beginning, middle and end of each experimental cycle to assess the availability of dry matter (DM). Samples were collected using a 1-square-meter sampling frame launched 20 times at random in each paddock. The forage contained in each sampling frame was cut and weighed. A subsample was weighed and ovendried to constant weight at $65^{\circ} \mathrm{C}$ to assess the DM.

\section{Weight gain and parasitological methods}

Animals were weighed after fasting for 18 hours, and feces collection and $R$. (B.) microplus, D. hominis larvae and $H$. irritans counts were performed every 28 days. The EPG was assessed using the Gordon and Whitlock (1939) method. Tick counts were performed according to Wharton and Utech (1970) and horn fly counting according to Bianchin and Alves (2002); $D$. hominis larvae were counted in the whole body. Daily, during protein supplementation in the morning the two groups, treated with neem oil and acaricide formulation were monitored for reinfestation by $H$. irritans.

Four sample collections of engorged female parasites obtained from animals undergoing each treatment were obtained during the period of allopathic acaricide application (September to January). The engorged females were weighed and incubated to measure the mass of eggs laid and hatching percentage to calculate the egg production index (EPI = (weight of eggs/weight of engorged females) x 100) (BENNETT, 1974, Reproductive Index (RI = (weight of eggs laid $\times 20000 \times \%$ hatching/weight of engorged females) and acaricidal efficacy (RI control - RI treated/ RI control) x100 (DRUMOND et al., 1973).

\section{Immune response}

Thirty animals from each treatment group were randomly chosen at the beginning and middle of the first experimental cycle (July 2010 and December 2010, respectively) for blood and serum sample collection. Packed cell volume (PCV) and differential leukocyte count were assessed using the methods described by Birgel (1982), and total IgG and IgG against Haemonchus placei were measured in the serum samples. Total $\operatorname{IgG}$ quantification was performed using an ELISA kit from Bethyl Laboratories for quantification of bovine IgG according to the manufacturer's instructions. Briefly, 96-well polystyrene plates (Costar 3590) were incubated with capture antibody for 1 hour at $37^{\circ} \mathrm{C}$. After five washings, $200 \mu \mathrm{l} /$ well blocking solution was added and the plates were incubated for 30 minutes. After five washings, test sera were incubated in a volume of $100 \mu \mathrm{l} /$ well for 1 hour at $37^{\circ} \mathrm{C}$. After five washings, peroxidase-conjugated detection antibody was added in a volume of $100 \mu \mathrm{l} /$ well, and the plates were incubated for 1 hour. After five washings, $100 \mu \mathrm{l} /$ well of substrate solution containing 3,3',5,5'-tetramethylbenzidine (TMB) was added, and the plates were incubated for 15 minutes in the dark. The reactions were stopped by the addition of $100 \mu \mathrm{l} /$ well of stop solution, and the absorbance was read at $450 \mathrm{~nm}$. The concentration of IgG in test sera was assessed by interpolation from a standard curve obtained with control sera of known IgG concentration.

Cryopreserved third-stage larvae (L3) were used to assess serum levels of IgG against Haemonchus placei. The larvae were washed in sterile saline and macerated. A soluble extract was prepared by ultrasound sonication of the macerated larvae, and the concentration of protein in the extract was determined using the Bradford method (1976). Polystyrene 96-well plates (Costar 3590) were incubated with $200 \mu \mathrm{g} / \mathrm{mL}$ of extract diluted in carbonate/bicarbonate buffer, $\mathrm{pH} 9.6$, for $18 \mathrm{~h}$ at $4{ }^{\circ} \mathrm{C}$. Serial dilutions of control sera from helminth-free bovines and animals experimentally infected with $H$. placei were tested by incubation with peroxidase-conjugated bovine anti-IgG. The dilutions that permitted the best distinction between samples positive and negative for antibodies against $H$. place $i$ were selected. To perform the experimental tests, the plates were blocked with $100 \mu \mathrm{l} /$ well phosphate-buffered saline with $0.01 \%$ Tween-20 (PBS-T) containing $5 \%$ skim milk powder for 1 hour at $37{ }^{\circ} \mathrm{C}$ following antigen adsorption. After five washes in PBS-T, serum samples diluted in PBS-T $(100 \mu \mathrm{L} /$ well $)$ were incubated in the wells for 1 hour at $37^{\circ} \mathrm{C}$. After five washings in PBS-T, $50 \mu \mathrm{L} /$ well of peroxidaseconjugated bovine anti-IgG diluted in PBS-T was added. After incubation for 30 minutes at $37^{\circ} \mathrm{C}$, the plates were washed and SIGMAFAST $^{\mathrm{TM}}$ OPD (o-phenylenediamine dihydrochloride) chromogenic substrate was added. After 10 minutes, the reactions were stopped by addition of $1 \mathrm{~N}$ sulfuric acid. The results were read on a microplate absorbance spectrophotometer (Bio-Rad) using a $490 \mathrm{~nm}$ filter. All samples and standard sera were tested in duplicate.

\section{Statistical analysis}

The following statistical model was used to examine the effect of treatment on the hematological and biochemical characteristics of the animals' blood samples:

$Y_{i j k l}=\mu+$ Treat $_{i+}$ Pad $_{k}($ Treat $)+$ Sampling $_{l}+$ Treat $_{i}^{*}$ Sampling $_{l}+\varepsilon_{i j k l}$

where $Y=$ the hematologic or biochemical value found in the $\mathrm{l}^{\text {th }}$ sample collection from the $\mathrm{i}^{\text {th }}$ animal maintained in the $\mathrm{k}^{\text {th }}$ paddock receiving the $\mathrm{j}^{\mathrm{th}}$ treatment; $\mu=$ the mean value found in a given hematologic or biochemical analysis; Treat $=$ the effect of the $\mathrm{j}^{\text {th }}$ treatment $(\mathrm{NC}, \mathrm{HH}, \mathrm{PC}, \mathrm{HF}$ and FN); Pad(Treat) $=$ the variation between paddocks for each treatment; Sampling $=$ the variation between pre-and post-treatment sample collection; and Treat ${ }^{*}$ Sampling $=$ the interaction between pre-and post-treatment 
sample collection for each treatment; $\varepsilon=$ the error associated with measurements performed on each experimental unit (animal). The similarity between treatments and the null hypothesis was evaluated considering the presence $(\mathrm{P}<0.05)$ or absence of the effect resulting from the interaction between treatments and sample collection.

The following statistical model was used to evaluate the effect of treatments on the animals' weight gain:

$Y_{i j k l=} \mu+$ Treat $_{i+}$ Pad $_{k}\left(\right.$ Treat $\left._{l}\right)+$ Year $_{l}+$ Treat $_{i}^{*}$ Year $_{l}+$ Winit $+\varepsilon_{i j k l}$

where $Y=$ the weight gained by the $\mathrm{i}^{\text {th }}$ animal maintained in the $\mathrm{k}^{\text {th }}$ paddock receiving the $\mathrm{j}^{\text {th }}$ treatment in the $\mathrm{l}^{\text {th }}$ year; $\mu=$ the weight gain mean value; Treat $=$ the effect of the $\mathrm{j}^{\text {th }}$ treatment (NC, HH, PC, HF and FN ); Pad(Treat) = the variation between paddocks for each treatment; Year $=$ the production period $\left(1^{\text {st }}\right.$ or $\left.2^{\text {nd }}\right)$; Treat ${ }^{*}$ Year $=$ the interaction between the values obtained for each treatment and the production year; Winit = the effect of the covariate weight at the start of the experiment; and $\varepsilon=$ the error associated with measurements performed on each experimental unit (animal). The similarities between treatments and the null hypothesis were evaluated by the difference in weight gain $(\mathrm{P}<0.05)$ between treatments.

The foregoing model, excluding live weight as covariate, was also used to evaluate infestation by parasites (horn flies, ticks and EPG). Given the negative binomial distribution observed, the number of ticks, horn flies and EPG were transformed to $\log _{10}(x+1)$. Data regarding the months from October to January, the period of application of the strategic allopathic treatment, were used to analyze the effects of treatment on tick and horn fly infestations. The statistical model included only the effect of treatments on the biological characteristics of ticks recovered from the animals. A model that included the effect of treatments and paddocks within each treatment was used to analyze the effects of pasture dry matter content. The GLM (Generalized Linear Model 2010) procedure of the SAS (2010) was used; when there was an effect of treatments $(\mathrm{P}<0.05)$, the adjusted means were compared using the Tukey-Kramer test.

\section{Results and Discussion}

In the first sample collection in June 2010, the DM availability was high given the pasture rest period before the start of the experiment; subsequently, it remained between 2 and 6 ton/ha. No significant difference in DM availability was observed between treatments $(P>0.05)$ in the two study years or in any of the sample collections obtained; thus, fodder was similarly available to animals in the different anti-parasite treatment groups (Figure 1).

\section{Humoral and cellular immune response}

The levels of total IgG and anti- $H$. placei IgG and the percentage of eosinophils and PCV ranged from $10.8 \mu \mathrm{g} / \mathrm{mL}$ to $171.8 \mu \mathrm{g} / \mathrm{mL}$, $0.30 \mathrm{OD}$ to $0.98 \mathrm{OD}, 0.0 \%$ to $15 \%$, and $29 \%$ to $58 \%$, respectively, between the first and second sample collections in all treatment groups. For the four variables assessed (total IgG, anti-H. placei

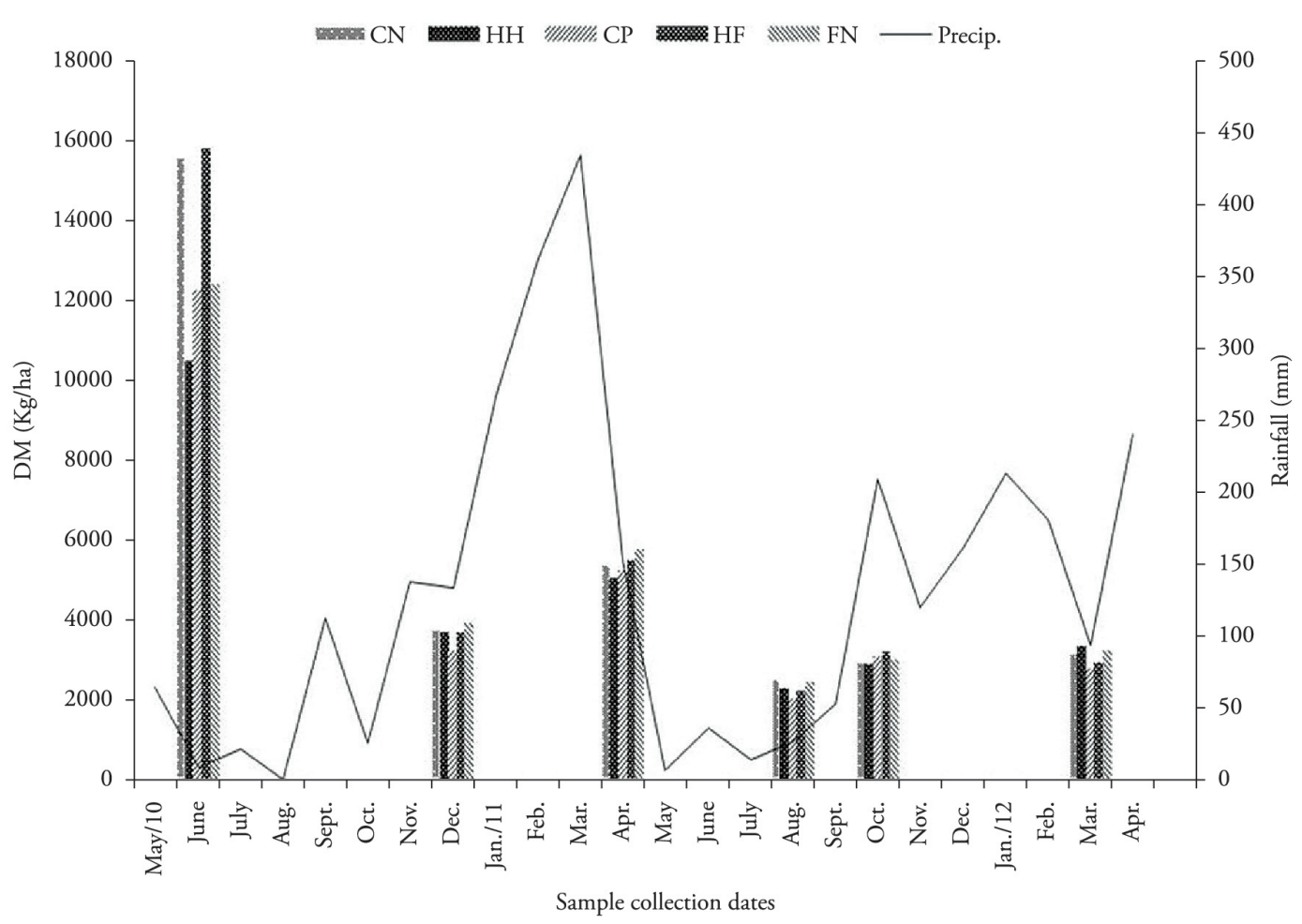

Figure 1. Pasture dry matter (DM) availability and rainfall during the experimental period. NC (negative control), untreated animals; HH, animals treated daily with Homeo bovis parasitário ${ }^{\circledR}$ homeopathic preparation; PC (positive control), animals treated strategically with allopathic anti-parasite drugs; HF, animals treated daily with Fator C\&MC ${ }^{\circledR}$ homeopathic preparation; and FN, animals treated daily with neem cake and strategically treated with neem oil (Bioneem $\left.{ }^{\circledR}\right)$. 
IgG, percentage of eosinophils and packed cell volume), there were no significant differences $(P>0.05)$ between the differences of the mean levels and percentages observed at the beginning and middle of the first experimental cycle, highlighting the absence of treatment effects on the immune response (Table 1). With the exception of the percentage of eosinophils in peripheral blood, the studied variables were lower in the second sample collection in all treatment groups.

In the present study, it was not possible to identify significant differences in the levels of total IgG and anti- $H$. placei IgG between treatments. By limitations in our laboratory, only the levels of anti-H. placei $\mathrm{IgG}$ were assessed. However, in addition to $\mathrm{IgG}$, other components of the immune system are important in protective response against helminth infections, and cross-reaction between trichostrongylids are frequent (NISHI et al., 2002).

Cytokines, such as IL-4, IL-13 and TNF- $\alpha$, are increased in the abomasal lymph nodes from animals infected with $\mathrm{L} 3$ of $H$. place $i$, whereas in the abomasal mucosa, IL-13 is increased and TNF- $\alpha$ is decreased, suggesting a Th2 polarization. Although the ancillary cellular components of the Th2 responses, such as mast cells and eosinophils, are very important in immunity to gastrointestinal helminths, in the initial steps of the infection with L3 $H$. placei, there was no increase in the count of these cells in primo-infected animals, suggesting that the cellular infiltrate takes longer to develop (IBELLI et al., 2011).

In cattle resistant to helminth infection, showing low EPG in the faeces, this phenotype was associated with increased expression of IL-4 and IL-13 (Th2), high serum levels of IgG1 against L3 and adults of $H$. placei, and greater numbers of mast cells in the mucosa of the abomasum (ZAROS et al., 2010). IgE levels were higher in Nellore cattle resistant to natural infections by gastrointestinal nematodes (BRICARELLO et al., 2007)

One possible explanation for the effects of homeopathic treatment on parameters related to immune system function is that homeopathic treatment may act to increase the immune response by stimulating the whole body (ZACHARIAS et al., 2008), similar to vaccination and allergy hyposensitization in conventional medicine (VOCKEROTH, 1999). On this issue, studies in veterinary parasitology have produced conflicting results. Zacharias et al. (2008) found no significant difference in the number of eosinophils, levels of total $\mathrm{IgG}$ or levels of anti- $H$. contortus IgG in the peripheral blood of sheep treated using homeopathy medicines, Ferrum phosphoricum, Arsenicum album and Calcarea carbonica; however, based on the significant decrease in $H$. contortus larvae observed in stool tests of the treated animals compared to the control group, these authors suggest that a decrease in $H$. contortus oviposition occurred in the treated animals due to an increased immune response. There was also no effect of homeopathic treatment, Sulphur, Calcarea phosphorica, Mercurius solubilis, Belladonna and Phytolacca on the cellular immune response to phytohemagglutinin in delayed hypersensitivity in Merino sheep, although it was suggested that homeopathy might stimulate defense and self-healing mechanisms (BRAGHIERI et al., 2007).

\section{Parasitological data}

No $D$. hominis larvae were found in the animals in either study cycle. For the other parasites studied, the model showed no significant effect of paddocks within treatment and no significant interaction between treatment and year. However, year (study cycle) had a significant effect on the three parasitic diseases: infestation by horn flies was higher in the second cycle $(1.56 \pm 0.02)$ than in the first $(1.21 \pm 0.02 ; \mathrm{P}<0.001)$, while infestation with ticks was higher in the first cycle $(0.62 \pm 0.02)$ than in the second $(0.24 \pm 0.02$; $\mathrm{P}<0.01)$. The EPG was also significantly higher in the first cycle $(1.48 \pm 0.05)$ than in the second $(1.29 \pm 0.05 ; \mathrm{P}<0.01)$.

Horn fly. Horn fly infestations showed features similar to those observed in previous studies conducted in the region (BIANCHIN; ALVES, 2002; BIANCHIN et al., 2006). The mean number of infestations was low between May and October ( $x=5$ to 40$)$ of both cycles, peaking in November and December $(x=160$ and $170)$ of the first cycle and in November and April ( $x=190$ and 110 ) of the second cycle. There were no significant effects of any of the treatments on horn fly infestation in either the first or second cycle or when the results were evaluated over both cycles (Table 2). In this study, field observations have shown that neem oil had a strong repellent effect for less than 16 hours. On the other hand, the acaricid treatment with pour-on formulations prevents reinfestation for a period of 7 to 10 days after treatment. Despite of this observation the mean of counted flies did not differ significantly of the others groups because the counts were taken every 28 days.

Neem cake added at $2 \%$ ratio to the mineral mixture also failed to reduce infestation by horn flies in Nellore bovines treated for two months (CHAGAS et al., 2010).

Tick. All groups of animals had a mean ticks number of $5.0 \pm 0.78$ and $15.9 \pm 1.74$ at the start of the first and of the second cycle, respectively. The annual mean number of engorged female ticks found on crossbred animals of European origin was

Table 1. Mean differences $( \pm$ SE) of total IgG, anti-Haemonchus placei IgG, packed cell volume and percentage of eosinophils in untreated heifers and in heifers treated with allopathy, homeopathy or herbal drugs five months after the start of treatment.

\begin{tabular}{lccccc}
\hline \multicolumn{1}{c}{ Treatments } & NC & HH & PC & HF & FN \\
\hline Total IgG $(\mu \mathrm{g} / \mathrm{mL})$ & $-12.9 \pm 7.4$ & $-14.8 \pm 5.5$ & $-25.6 \pm 15.3$ & $-25.0 \pm 6.9$ & $-17.1 \pm 7.4$ \\
Haemonchus placei IgG (OD) & $-0.03 \pm 0.04$ & $+0.01 \pm 0.02$ & $-0.01 \pm 0.02$ & $-0.01 \pm 0.03$ & $-0.05 \pm 0.04$ \\
Packed cell volume (\%) & $-5.5 \pm 1.3$ & $-5.1 \pm 0.8$ & $-4.2 \pm 0.8$ & $-5.2 \pm 1.0$ & $-4.4 \pm 1.3$ \\
Eosinophils $(\%)$ & $+1.12 \pm 2.43$ & $+2.49 \pm 1.61$ & $+3.64 \pm 1.37$ & $+3.15 \pm 1.24$ & $+3.90 \pm 2.60$ \\
\hline
\end{tabular}

$\mathrm{NC}$ (negative control), untreated animals; $\mathrm{HH}$, animals treated daily with Homeobovis parasitário ${ }^{\circledR}$ homeopathic preparation; PC (positive control), animals treated strategically with allopathic anti-parasite drugs; HF, animals treated daily with Fator C\&MC ${ }^{\circledast}$ homeopathic preparation; FN, animals treated daily with neem cake and strategically with neem oil - Bioneem ${ }^{\circledR}$. SE, standard error. 
Table 2. Means $( \pm$ SE) number of nematode eggs (EPG), tick and horn fly and weight gain of beef heifers subjected to various anti-parasite treatments.

\begin{tabular}{|c|c|c|c|c|c|}
\hline & Treatment & EPG & Ticks $^{1}$ & Horn Fly ${ }^{1}$ & Weight gain (kg) \\
\hline \multirow[t]{5}{*}{ Year 1} & $\mathrm{NC}$ & $202(60)$ & $12.3(2.6)^{c}$ & $106(23)$ & $56.7(4.8)^{\mathrm{b}}$ \\
\hline & $\mathrm{HH}$ & $281(76)$ & $13.2(3.4)^{\mathrm{bc}}$ & $95(22)$ & $62.2(3.5)^{\mathrm{b}}$ \\
\hline & PC & $134(53)$ & $1.4(0.7)^{\mathrm{a}}$ & $118(24)$ & $96.1(3.4)^{\mathrm{a}}$ \\
\hline & $\mathrm{HF}$ & $226(56)$ & $5.2(1.4)^{\mathrm{b}}$ & $102(27)$ & $69.6(4.3)^{\mathrm{b}}$ \\
\hline & $\mathrm{FN}$ & $240(64)$ & $10.6(2.9)^{c}$ & $76(18)$ & $66.4(5.0)^{\mathrm{b}}$ \\
\hline \multirow[t]{5}{*}{ Year 2} & $\mathrm{NC}$ & $217(94)^{\mathrm{b}}$ & $1.7(0,6)$ & $111(18)$ & $61.3(4.6)^{b}$ \\
\hline & $\mathrm{HH}$ & $205(63)^{b}$ & $2.0(0.6)$ & $102(17)$ & $63.4(3.3)^{\mathrm{b}}$ \\
\hline & PC & $93(55)^{\mathrm{a}}$ & $0.4(0.2)$ & $119(22)$ & $83.1(3.2)^{\mathrm{a}}$ \\
\hline & $\mathrm{HF}$ & $171(49)^{\mathrm{b}}$ & $3.3(1.6)$ & $99(19)$ & $64.8(3.9)^{\mathrm{b}}$ \\
\hline & $\mathrm{FN}$ & $173(55)^{\mathrm{b}}$ & $1.5(0.6)$ & $93(22)$ & $64.6(4.4)^{\mathrm{b}}$ \\
\hline \multirow[t]{5}{*}{ Years 1 and 2} & $\mathrm{NC}$ & $209(56)^{b}$ & $7.0(1.5)^{b}$ & $109(15)$ & $58.9(3.3)^{\mathrm{b}}$ \\
\hline & $\mathrm{HH}$ & $243(49)^{b}$ & $7,6(1.8)^{\mathrm{b}}$ & $98(140$ & $62.7(2.4)^{b}$ \\
\hline & PC & $114(38)^{\mathrm{a}}$ & $0.9(0.3)^{\mathrm{a}}$ & $118(16)$ & $89.5(2.4)^{\mathrm{a}}$ \\
\hline & $\mathrm{HF}$ & $201(41)^{b}$ & $4.3(1.0)^{\mathrm{b}}$ & $101(16)$ & $67.2(4.8)^{\mathrm{b}}$ \\
\hline & $\mathrm{FN}$ & $201(42)^{b}$ & $5.9(1.6)^{b}$ & $82(14)$ & $65.4(4.8)^{\mathrm{b}}$ \\
\hline
\end{tabular}

${ }^{1}$ Means $( \pm$ SE) number of tick and horn fly from October to January, the period of application of the strategic allopathic treatment. NC (negative control), untreated animals; $\mathrm{HH}$, animals treated daily with Homeobovis parasitário ${ }^{\circledR}$ homeopathic preparation; PC (positive control), animals treated strategically with allopathic anti-parasite drugs; HF, animals treated daily with Fator $\mathrm{C} \& \mathrm{MC}{ }^{\circledR}$ homeopathic preparation; FN, animals treated daily with neem cake and strategically with neem oil- Bioneem ${ }^{\circledast}$. Values in the same column with dissimilar superscript letters are significantly different at $P<0.05$. SE, standard error.

low in all treatments and in both experimental cycles. The highest rates of tick infestation occurred in October $(\mathrm{x}=21)$ and January $(\mathrm{x}=11)$ of the first cycle and in January and April $(\mathrm{x}=4)$ of the second cycle. This observation likely accounts for the lack of a significant effect of treatment on tick infestation in the second cycle, although the mean infestation level in the animals that received strategic treatment (PC) was approximately four times lower than the infestation level in the other treated groups. In the first cycle the annual mean tick infestation level was significantly lower in animals that received PC treatment than in animals that received other treatments, the HF animals showed mean tick infestation levels similar to those of the $\mathrm{HH}$ animals and significantly lower than those of the NC and FN animals. Silva et al. (2008) in heifers naturally infested and treated with Fator $C \& M C^{\circledR}$, also observed a significant decrease in the number of ticks in relation to control group. However, other authors with the same homeopathic, Fator $\mathrm{C} \& M \mathrm{MC}^{\circledR}$, have failed to find differences in the number of female ticks in naturally infested male dairy calves treated for eight months (SIGNORETTI et al., 2008) and in experimentally infested crossbred animals (COSTA-JUNIOR; FURLONG, 2011). When evaluated over both cycles mean tick infestation was significantly lower in the PC treated-animals than in the other treatment groups (Table 2).

In December of the first cycle, a peak in infestation by tick larvae triggered the occurrence of 38 cases of myiasis. Nine of these cases occurred in NC-treated animals, nine in $\mathrm{HH}$-treated animals, one in the PC treatment group, 11 in the HF treatment group and seven in the FN treatment group. The affected animals in the $\mathrm{NC}, \mathrm{HH}, \mathrm{HF}$ and $\mathrm{FN}$ treatment groups were treated with the same acaricide used in the PC-treated animals to ensure animal wellness and to interrupt the effect of myiasis on weight gain.

Pour-on treatment with neem oil at 28-day intervals failed to significantly decrease mean infestation by $R$. (B.) microplus in this study. Kalakumar et al. (2000) evaluated the acaricidal activity of neem oil against $R$. (B.) microplus, Hyalomma anatolicum anatolicum and $R$. haemaphysaloides and found 60-75\% efficiency in bovines and buffaloes.

Srivastava et al. (2008) and Magadum et al. (2009) found 71\% mortality of ticks 5 to 7 days post-treatment using an ethanolic extract of $A$. indica ( $8 \%$ ) seeds in experimentally infested crossbred steers, and Valente et al. (2007) found an effect similar to that of abamectin pour-on in naturally infested bovines treated weekly for a month with an aqueous extract of neem leaf. However, Ramzan et al. (2008), using dried leaves topically applied in water, concluded that the efficacy of $A$. indica in controlling infestation by R. (B.) microplus, B. annulatus, and Hyalomma aegyptium was $0 \%$.

Except for weight, there was no effect of treatment $(\mathrm{P}>0.05)$ on the measured variables for engorged female ticks collected from animals in the different treatment groups. Engorged female ticks from the $\mathrm{PC}$-treated animals weighed significantly less $(\mathrm{P}<0.05)$ than those obtained from the $\mathrm{NC}, \mathrm{HH}$ and $\mathrm{HF}$-treated animals; females collected from the FN-treated animals were of similar weight to those collected from animals in all other treatment groups (Table 3).

The observed significant reduction in the weight of engorged female ticks from the PC-treated animals and the smaller reduction in the weight of female ticks collected from FN-treated animals most likely reflects the residual effect of treatment with acaricide and neem oil. Kalakumar et al. (2000) also noted an effect of a commercial neem oil formulation on oviposition of $H$. anatolicum anatolicum, $R$. haemophysaloides and $R$. (B.) microplus. Srivastava et al. (2008) and Magadum et al. (2009) reported a significant reduction in the weight of engorged female ticks, oviposition and the reproductive index of ticks that fed on experimentally infested bovines treated with ethanolic extracts ( $8 \%)$ of $A$. indica leaves. 
Engorged female ticks fed on cattle treated for 28 months with a tick biotherapic 12 and $30 \mathrm{CH}$ added to the mineral salt provided showed significantly decreased weight, oviposition and egg mass and a consequent decrease in reproductive efficiency (GAZIM et al., 2010). The results of Gazin et al. differ from those obtained in this study and in the study of Costa-Junior and Furlong (2011) in experimentally infested 7:8 Holstein:Zebu crossbred animals; the former authors reported no statistically significant reduction in weight of females or in egg production index in animals treated with homeopathic products.

EPG. All groups of animals in this study had a mean ( \pm ep) EPG of approximately $700 \pm 180$ at the start of the two cycles study; at the completion of both experimental cycles, all groups had a mean EPG of approximately 100, showing a decrease in parasitism with increase in age. Similar results have been reported in previous studies conducted in the same region of Brazil (BIANCHIN et al., 1995, 2007; CATTO et al., 2009). In the second cycle and over both cycles, the mean EPG in the PC-treated animals was significantly lower than in the animals in any of the other treatment groups. The smaller difference observed in the first cycle was not statistically significant (Table 2).

In 10-month-old male dairy bovines, Signoretti et al. (2008) found no significant difference in EPG between untreated animals and animals treated using Fator C\&MC homeopathy for a period of 8 months, similar to the results obtained in this study. Several trials that assessed EPG in sheep also reported no significant difference between untreated animals and animals treated using homeopathy preparation Fator Vermes ${ }^{\circledR}$ (DA ROCHA et al., 2006; CHAGAS et al. 2008), Ferrum phosphoricum, Arsenicum album and Calcarea carbonica (ZACHARIAS et al., 2008) or Sulphur,
Ferrum phosphoricum, Arsenicum album and Mercurius solubilis (CAVALCANTI et al., 2007).

Iqbal et al. (2010) noted 29\% and 40\% reduction in EPG in sheep treated with powder or methanolic extract of $A$. indica seeds. In this study the daily treatment of heifers with neem cake not significantly decreased EPG as compared with the control group, results similar to those obtained by Chagas et al. (2008) that found no effect of treatment with ground dried leaves of $A$. indica and Costa et al. (2006) feeding sheep with dry, crushed leaves of $A$. indica.

No significant reduction in the percentage of $H$. contortus larvae in stool tests, which would suggest a decrease in oviposition via an increase in the animals' immune response observed by (ZACHARIAS et al., 2008), was found in the percentage of larvae of $H$. place $i$ in stool tests from bovines treated with homeopathy in the present study (Table 4).

Weight gain. All groups of animals had a mean ( \pm ep) live weight of $194 \pm 2.5$ and $200 \pm 1.7$ at the start of the first and of the second cycle, respectively. The animals in this study gained significantly more weight in the first cycle $(70.9 \pm 1.660)$ than in the second cycle $(66.6 \pm 1.66)$. As with parasitism, there was no significant paddock effect within each treatment and no interaction between treatment and year. The PC-treated animals that were strategically treated with allopathic drugs gained significantly more weight than the untreated animals (NC) and than animals treated using homeopathy ( $\mathrm{HH}$ and $\mathrm{HF}$ ) or with herbal drugs (FN); the latter groups showed no significant differences in weight gain in either experimental cycle (Table 2). The animals that were strategically treated with anthelmintic and acaricide gained between 22 and $30 \mathrm{~kg}$ live weight $(\mathrm{P}<0.05)$ more on average than animals receiving any of the other treatments in both years.

Table 3. Mean $( \pm \mathrm{SD})$ weight of engorged females, egg hatching rate, egg production index and acaracidal efficacy of $R$. (B.) microplus from beef heifers subjected to various antiparasitic treatments.

\begin{tabular}{ccccc}
\hline Treatment & $\begin{array}{c}\text { Weight of engorged } \\
\text { females }(\mathbf{m g})\end{array}$ & Egg hatching (\%) & EPI (\%) & Efficacy (\%) \\
\hline NC & $217.6(10.9)^{\mathrm{b}}$ & $92.0(4.2)$ & $50.0(2.4)$ & -0.81 \\
HH & $209.1(10.9)^{\mathrm{b}}$ & $90.3(4.2)$ & $51.3(2.4)$ & 12.46 \\
PC & $165.0(13.4)^{\mathrm{a}}$ & $91.5(5.2)$ & $43.5(2.9)$ & 13.48 \\
HF & $211.3(10.9)^{\mathrm{b}}$ & $83.2(4.2)$ & $48.0(2.4)$ & 6.43 \\
FN & $195.0(10.9)^{\mathrm{ab}}$ & $88.3(4.2)$ & $47.3(2.4)$ & \\
\hline
\end{tabular}

$\mathrm{NC}$ (negative control), untreated animals; $\mathrm{HH}$, animals treated daily with Homeobovis parasitário ${ }^{\circledR}$ homeopathic preparation; $\mathrm{PC}$ (positive control), animals treated strategically with allopathic anti-parasite drugs; HF, animals treated daily with Fator C\&MC ${ }^{\circledast}$ homeopathic preparation; FN, animals treated daily with neem cake and strategically with neem oil - Bioneem ${ }^{\circledR}$. Values in the same column with dissimilar superscript letters are significantly different at $P<0.05$. SD, standard deviation.

Table 4. Percentage of larvae per gender $( \pm S E)$ determined from stool tests performed during the experimental period.

\begin{tabular}{ccccc}
\hline Treatment & Cooperia & Haemonchus & Trichostrongylus & Oesophagostomum \\
\hline NC & $37(0.05)$ & $54(0.05)$ & $1(0.00)$ & $8(0.01)$ \\
HH & $28(0.04)$ & $64(0.04)$ & $1(0.01)$ & $7(0.01)$ \\
PC & $45(0.08)$ & $36(0.08)$ & $0(0.00)$ & $19(0.06)$ \\
HF & $34(0.05)$ & $60(0.05)$ & $1(0.00)$ & $5(0.01)$ \\
FN & $35(0.04)$ & $58(0.04)$ & $1(0.00)$ & $6(0.01)$ \\
\hline
\end{tabular}

NC (negative control), untreated animals; HH, animals treated daily with Homeobovis parasitário ${ }^{\circledR}$ homeopathic preparation; PC (positive control), animals treated strategically with allopathic anti-parasite drugs; HF, animals treated daily with Fator C\&MC ${ }^{\circledR}$ homeopathic preparation; FN, animals treated daily with neem cake and strategically with neem oil- Bioneem ${ }^{\circledR}$. SE, standard error. 
In a similar trial in the state of Rio de Janeiro, Pinheiro et al. (2009) monitored the development of male Nelore and 1/2 Red Angus-Nelore bovines treated with a biotherapic Fator C\&MC or strategically treated using allopathic products against ecto- and endoparasites from weaning to 30 months of age. The animals treated using allopathy had an average live weight at slaughter $47 \mathrm{~kg}$ greater $(\mathrm{P}<0.05)$ than that of the animals treated with the biotherapic. In studies evaluating the weight gain of heifers treated with Factor C\&MC ${ }^{\circledR}$ during 12 months, Silva et al. (2008) and Signoretti et al. (2008) found no difference in weight gain between the treated and untreated animals.

In this study horn fly infestation was not influenced by any of the treatments; the use of strategic treatment with allopathic drugs was effective in controlling EPG and tick infestation and provided a weight gain increase of 22 to $30 \mathrm{~kg}$ live weight/animal compared to untreated animals or animals treated with alternative drugs.

\section{Acknowledgments}

The authors are especially grateful to the rancher Arno Seemann for providing the experimental animals for the two-year study with the awareness that they could be unprotected from parasites during that time, as well as to the agricultural technicians and laboratory assistants Marco Antonio da Silva and Ronaldo Luiz da Silva for performing the fieldwork and laboratory work.

\section{References}

Barros ATM, Saueressig TMS, Gomes A, Koller WW, Furlong J, Girão ES, et al. Susceptibility of the horn fly, Haematobia irritans irritans (Diptera: Muscidae), to insecticides in Brazil. Rev Bras Parasitol Vet 2012; 21(2): 125-132. PMid:22832752. http://dx.doi.org/10.1590/ S1984-29612012000200010

Bennett GF. Oviposition of Boophilus microplus (Canestrini) (Acarida: Ixodidae). II. Influence of temperature, humidity and light. Acarologia 1974; 16(2): 251-257. PMid:4466310.

Bianchin I, Alves RGO. Mosca-dos-chifres Haematobia irritans: comportamento e danos em vacas e bezerros Nelore antes da desmama. Pesq Vet Bras 2002; 22(3): 109-113. http://dx.doi.org/10.1590/S0100736X2002000300004

Bianchin I, Catto JB, Kichel AN, Torres RAA Jr, Honer MR. The effect of the control of endo and ectoparasites on weight gains in crossbred cattle (Bos taurus $\mathrm{x}$ Bos taurus indicus) in the central region of Brazil. Trop Anim Health Prod 2007; 39(4): 287-296. PMid:17847824. http:// dx.doi.org/10.1007/s11250-007-9017-1

Bianchin I, Honer MR, Nunes S, Do Nascimento YA. Effect of stocking rates and anthelmintic treatments on weight gains in weaned Nellore cattle on improved pasture in the Brazilian savanna. Trop Anim Health Prod 1995; 27(1): 1-8. PMid:7770946. http://dx.doi.org/10.1007/ BF02236326

Bianchin I, Koller WW, Detmann E. Sazonalidade de Haematobia irritans no Brasil Central. Pesq Vet Bras 2006; 26(2): 79-86. http://dx.doi. org/10.1590/S0100-736X2006000200004

Birgel EH. Hematologia clínica veterinária. In: Birgel EH, Benesi FJ, editors. Patologia Clínica Veterinária. São Paulo: Sociedade Paulista de Medicina Veterinária; 1982. p. 2-34.
Borges LMF, Souza LAD, Barbosa CS. Perspectives for the use of plant extracts to control the cattle tick Rhipicephalus (Boophilus) microplus. Rev Bras Parasitol Vet 2011; 20(2): 89-96. PMid:21722481. http://dx.doi. org/10.1590/S1984-29612011000200001

Bradford M. A rapid and sensitive method for the quantitation of microgram quantities of protein utilizing the principle of proteindye binding. Anal Biochem 1976; 72(1-2): 248-254. http://dx.doi. org/10.1016/0003-2697(76)90527-3

Braghieri A, Pacelli C, Verdone M, Girolami A, Napolitano F. Effect of grazing and homeopathy on milk production and immunity of Merino derived ewes. Small Ruminant Res 2007; 69(1-3): 95-102. http://dx.doi. org/10.1016/j.smallrumres.2005.12.014

Brasil. Ministério da Agricultura Pecuária e Desenvolvimento. Instrução Normativa no 64 de 18 de dezembro de 2008. Aprova o Regulamento Técnico para os Sistemas Orgânicos de Produção Animal e Vegetal. Diário Oficial da República Federativa do Brasil, Brasília, 19 dez. 2008. Seção 1, p. 21.

Bricarello PA, Zaros LG, Coutinho LL, Rocha RA, Kooyman FN, De Vries E, et al. Field study on nematode resistance in Nelore-breed cattle. Vet Parasitol 2007; 148(3-4):272-278. PMid:17659839. http://dx.doi. org/10.1016/j.vetpar.2007.06.013

Catto JB, Bianchin I, Santurio JM, Feijó GLD, Kichel NA, Silva JM. Sistema de pastejo, rotenona e controle de parasitas em bovinos cruzados: efeito no ganho de peso e no parasitismo. Rev Bras Parasitol Vet 2009; 18(4): 37-43. PMid:20040207. http://dx.doi.org/10.4322/ rbpv.01804007

Cavalcanti ASR, Almeida MAO, Dias AVS. Efeito de medicamentos homeopáticos no número de ovos de nematódeos nas fezes (OPG) e no ganho de peso em ovinos. Rev Bras Saúde Prod An 2007; 8(3):162-169.

Chagas AC, Vieira LS, Freitas AR, Araújo MR, Araújo-Filho JA, Araguão WR, et al. Anthelmintic efficacy of neem (Azadirachta indica A. Juss) and the homeopathic product Fator Vermes in Morada Nova sheep. Vet Parasitol 2008; 151(1): 68-73. PMid:18022188. http://dx.doi. org/10.1016/j.vetpar.2007.10.003

Chagas ACS, Oliveira MSO, Giglioti R, Calura FH, Ferrenzini J, Forim MR, et al. Efficacy evaluation of a commercial neem cake for control of Haematobia irritans on Nelore cattle. Rev Bras Parasitol Vet 2010; 19(4): 217-221. PMid:21184697. http://dx.doi.org/10.1590/ S1984-29612010000400005

Costa CTC, Bevilaqua CML, Maciel MV, Camurça-Vasconcelos ALF, Morais SM, Monteiro MVB, et al. Anthelmintic activity of Azadirachta indica A. Juss against sheep gastrointestinal nematodes. Vet Parasitol 2006; 137(3-4): 306-310. PMid:16517074. http://dx.doi. org/10.1016/j.vetpar.2006.01.002

Costa-Junior LM, Furlong J. Efficiency of sulphur in garlic extract and non-sulphur homeopathy in the control of the cattle tick Rhipicephalus (Boophilus) microplus. Med Vet Entomol 2011; 25(1): 7-11. PMid:20819153. http://dx.doi.org/10.1111/j.1365-2915.2010.00909.x

Da Rocha RA, Pacheco RDL, Amarante AFT. Efficacy of homeopathic treatment against natural infection of sheep by gastrointestinal nematodes. Rev Bras Parasitol Vet 2006; 15(1): 23-27. PMid:16646998.

Drumond RO, Ernst SE, Trevino JL, Gladney WJ, Graham OH. Boophilus annulatus and Boophilus microplus: Laboratory Tests of insecticides. J Econ Entomol 1973; 66(1): 130-133.

Gazim ZC, Ferreira FBP, Silva AV, Bolognese KC, Merlin E, Messa $\mathrm{V}$, et al. Efficiency of tick biotherapic on the control of infestation by 
Rhipicephalus (Boophilus) microplus in Dutch dairy cows. Int J High Dilution Res 2010; 9(33):156-164.

Gordon HML, Whitlock HV. A new technique for counting nematode eggs in sheep faeces. J Counc Sci Indust Res 1939; 12: 50-52.

Graf JF, Gogolewski R, Leach-Bing N, Sabatini GA, Molento $\mathrm{MB}$, Bordin EL, et al. Tick control: an industry point of view. Parasitology 2004; 129(S): 427-442.

Ibelli AMG, Nakata LC, Andréo R, Coutinho LL, Oliveira MCS, Amarante AFT, et al. mRNA profile of Nellore calves after primary infection with Haemonchus placei. Vet Parasitol 2011; 176: 195-200. PMid:21144661. http://dx.doi.org/10.1016/j.vetpar.2010.11.013

Iqbal Z, Lateef M, Jabbar A, Gilani AH. In vivo anthelmintic activity of Azadirachta indica A. Juss seeds against gastrointestinal nematodes of sheep. Vet Parasitol 2010; 168(3-4): 342-345. http://dx.doi. org/10.1016/j.vetpar.2009.11.005

Kalakumar B, Kumar HSA, Kumar BA, Reddy KS. Evaluation of custard seed oil and neem oil as acaricides. J Vet Parasitol 2000; 14(2):171-172.

Kaminsky R, Ducray P, Jung M, Clover R, Rufener L, Bouvier J, et al. A new class of anthelmintics effective against drug-resistant nematodes. Nature 2008; 452(7184): 176-180. PMid:18337814. http://dx.doi. org/10.1038/nature06722

Magadum S, Mondal DB, Ghosh S. Comparative efficacy of Annona squamosa and Azadirachta indica extracts against Boophilus microplus Izatnagar isolate. Parasitol Res 2009; 105(4):1085-1091. http://dx.doi. org/10.1007/s00436-009-1529-3

Molento MB. Parasite control in the age of drug resistance and changing agricultural practices. Vet Parasitol 2009; 163(3): 229-234. PMid:19560869. http://dx.doi.org/10.1016/j.vetpar.2009.06.007

Nishi SM, Richtzenhain LJ, Gennari SM. Níveis de IgG séricos em bezerros experimentalmente infectados pelo Haemonchus placei. Braz J Vet Res Anim Sci 2002; 39 (2): 107-110. http://dx.doi.org/10.1590/ S1413-95962002000200010

Pinheiro RMK, Silva TJP, Viana JHM. Influência do grupo genético, condição sexual e tratamento antiparasitário nas medidas de área de olho do lombo e espessura de gordura in vivo e na carcaça de bovinos de corte. Arq Bras Med Vet Zootec 2009; 61(3): 676 -681. http://dx.doi. org/10.1590/S0102-09352009000300022
Ramzan M, Khan MS, Avais M, Khan JA, Pervez K, Shahzad W. Prevalence of ecto parasites and comparative efficacy of different drugs against tick infestation in cattle. J Anim Pl Sci 2008; 18(1): 17-19.

Signoretti RD, Veríssimo CJ, De Souza FHM, Garcia TS, Oliveira EM, De Souza KG, et al. Desempenho e infestação por parasitos em machos leiteiros suplementados com sal proteinado com ou sem os medicamentos homeopáticos. Rev Bras Parasitol Vet 2008; 17(S1): 40 44. PMid:20059813.

Silva NL, Moletta JL, Minho AP, Filippsen LF. Use of biotherapic in the control of natural infestation by Boophilus microplus: pilot study. Int J High Dilution Res 2008; 7(22): 36-38.

Sindicato Nacional da Indústria de Produtos para Saúde Animal - SINDAN. Mercado Veterinário. São Paulo. [online]. 2008 [cited 2012 oct]. Available from: http:// www.sindan.org.br/sd/sindan/ index.html.

Srivastava R, Ghosh S, Mandal DB, Azhahianambi P, Singhal OS, Pandey NN, et al. Efficacy of Azadirachta indica extracts against Boophilus microplus. Parasitol Res 2008; 104(1): 149-153. PMid:18769940. http:// dx.doi.org/10.1007/s00436-008-1173-3

Statistical Analisys System Institute - SAS. SAS User's Guide; Statistics, Version. Cary: SAS Institute, Inc.; 2010.

Valente M, Barranco A, Sellaive-Villaroel AB. Eficácia do extrato aquoso de Azadirachta indica no controle de Boophilus microplus em bovino. Arq Bras Med Vet Zootec 2007; 59(5): 1341-1343. http://dx.doi.org/10.1590/ S0102-09352007000500039

Vockeroth WG. Veterinary homeopathy: An overview. Can Vet J 1999; 40(8): 592-594. PMid:12001344 PMCid:PMC1539764.

Wharton RH, Utech KBW. The relation between engorgement and dropping of $B$. microplus (Canestrini) (Ixodidae) to the assessment of tick numbers on cattle. J Aust Ent Soc 1970; 9(3): 171-182. http://dx.doi. org/10.1111/j.1440-6055.1970.tb00788.x

Zacharias F, Guimarães JE, Araújo RR, Almeida MAO, Ayres MCC, Bavia ME, et al. Effect of homeopathic medicines on helminth parasitism and resistance of Haemonchus contortus in infected sheep. Homeopathy 2008; 97(3): 145-151. PMid:18657774. http://dx.doi. org/10.1016/j.homp.2008.05.004

Zaros LG, Bricarello PA, Amarante AFT, Rocha RA, Kooyman FN, De Vries E, et al. Cytokine gene expression in response to Haemonchus placei infections in Nelore cattle. Vet Parasitol 2010; 171(1-2): 68-73. PMid:20409640. http://dx.doi.org/10.1016/j.vetpar.2010.03.020 